Association for Information Systems

AIS Electronic Library (AISeL)

\title{
E-Service Touchpoints for Jewelry Retailers: Customers' Perceptions of a Digital Sales Desk
}

\author{
Cara Michelle Pfabe \\ Westfälische Wilhelms-Universität Münster \\ Benjamin Barann \\ Westfälische Wilhelms-Universität Münster \\ Ann-Kristin Cordes \\ Westfälische Wilhelms-Universität Münster \\ Andreas Hermann \\ Westfälische Wilhelms-Universität Münster \\ Torsten Gollhardt \\ Westfälische Wilhelms-Universität Münster
}

Follow this and additional works at: https://aisel.aisnet.org/wi2021

Pfabe, Cara Michelle; Barann, Benjamin; Cordes, Ann-Kristin; Hermann, Andreas; and Gollhardt, Torsten, "EService Touchpoints for Jewelry Retailers: Customers' Perceptions of a Digital Sales Desk" (2021). Wirtschaftsinformatik 2021 Proceedings. 2.

https://aisel.aisnet.org/wi2021/UDigitalRetail/Track06/2

This material is brought to you by the Wirtschaftsinformatik at AIS Electronic Library (AISeL). It has been accepted for inclusion in Wirtschaftsinformatik 2021 Proceedings by an authorized administrator of AIS Electronic Library (AISeL). For more information, please contact elibrary@aisnet.org. 


\title{
E-Service Touchpoints for Jewelry Retailers: Customers' Perceptions of a Digital Sales Desk
}

\author{
Cara M. Pfabe, Benjamin Barann, Ann-Kristin Cordes, \\ Andreas Hermann, and Torsten Gollhardt \\ University of Münster, ERCIS, Münster, Germany, \\ c.pfabe@uni-muenster.de, \{barann, cordes, hermann, gollhardt\}@ercis.de
}

\begin{abstract}
.
The digitalization of retail also affects the luxury industry. The integration of digital components in local retail stores can be one way to attract customers and stay competitive. One novel in-store technology for jewelry stores could be a digital sales desk intended to support the watch-advisory service. This work proposes a conceptual design for a digital sales desk comprising various e-service touchpoints. It conducts an ex-ante evaluation to investigate the aspects of the digital sales desk that influence customers' perceptions of quality and their reuse intentions toward the digitally enriched advisory service. Therefore, an online survey was conducted. The survey results indicate that some e-service touchpoints are more popular than others. The participants' quality and value perceptions also directly impacted their intentions to re-use the service. The results shed light on the digital sales desk's potentials and provide orientation regarding the most promising e-service touchpoints.
\end{abstract}

Keywords: Digital Transformation, Brick-and-Mortar, Jewelry Retail, E-Service, Touchpoint

\section{Introduction}

The online share for luxury goods has steadily grown and is expected to grow further [1]. This trend is also observable in the watch industry [2]. While the increase of online presence [3], and the use of social media in luxury retailing, can be commonly observed, stationary retailers in the luxury segment have to catch up regarding the adoption of mobile applications and in-store technologies [4]. Interactions with in-store technologies and touchpoints shape customers' experiences $[4,5]$. Furthermore, omnichannel experiences in physical stores [6] can drive the shopping intentions of customers [7]. As a result, luxury retailers and brands are searching for technologies to transform their physical stores [8] into an "experiential place" [9, p. 47]. However, they need to ensure that an in-store technology "is relevant for consumers [...] and really provides value for them [...]" [10, p. 99] and meets their own and their customers' expectations [9]. When purchasing irregularly purchased goods, customers have different expectations, and they demand, for example, detailed information and knowledgeable sellers [11]. Particularly, luxury customers expect high-quality products and services and are willing to pay for them $[12,13]$. Thus, novel in-store technologies for luxury retailers should be designed accordingly. 
This article focuses on a novel in-store technology for jewelry stores. In essence, it proposes a touchscreen-enabled digital sales desk (i.e., an IT artifact) supporting watchadvisory services in physical jewelry stores. As behavioral knowledge can support IT artifacts' design [14], this study conducts an artificial, formative, ex-ante evaluation [cf. 15] with potential customers to reduce the uncertainties and risks involved in implementing this retail technology [cf. 15, 16]. Whether customers use a technology depends on their perceptions of quality, value, and satisfaction [17-19]. Thus, this article aims at investigating the aspects of a digital sales desk that affect customers' quality perceptions and their intentions to (re-)use the digitally supported service. An online survey was conducted to reach this objective. The results shed light on a digital sales desk's potentials in jewelry stores and provide practical orientation on its most essential aspects, which need to be considered.

This article's remainder is structured as follows: Section 2 proposes the digital sales desk's concept. Section 3 develops the research model and presents the hypotheses. Section 4 elaborates on the research method. Next, the results are presented in Section 5 and discussed in Section 6 . The article concludes with a summary and an outlook.

\section{A Digital Sales Desk that Supports the Sale of Watches}

Luxury is often associated with excellent quality, exceptional craftsmanship, remarkable beauty, joy, global reputation, exclusivity, and rarity [12, 20, 21]. Next to high material value, luxury products also have an intangible value for the customer, which leads to an increased willingness to pay [4, 21]. In addition, emotions can impact luxury customers' brand attitudes [22]. Their perceptions of excellence value, functional value, experiential values, self-expressive value, social value, and economic value lead to positive brand relationships [12]. In turn, positive brand relationships [12] and affective attitude (e.g., pleasure or enjoyment) [20] can drive behavioral intentions [12] and purchase intentions [20]. Luxury customers often obtain detailed information about the products of interest beforehand [3]. Therefore, they "expect sophisticated personal service and special treatment" [12, p. 86]. Furthermore, the merchandising, product offering, store atmosphere, and interior design of the physical servicescape should match the luxury and status expected by customers [23].

"The Internet plays an important role as an information source on luxury products" [1, p. 28]. For example, online shops attract customers due to their convenience. Among others, relevant aspects of online shops are extensive product selections, easier product comparison, and access to brand information, product information, product presentations, and reviews [1]. Nevertheless, "physical stores are still the most relevant source of information on new personal luxury products" [1, p. 27]. They attract customers due to the physical [1,9] and direct availability [1] of authentic products [9], personal advice, purchasing experiences, and stores' ambient [1]. However, over the past few years, the online share for luxury goods has steadily grown and is expected to grow further [1]. Now, luxury brands have to become more digital to adapt to this trend. However, they need "to know the available digital opportunities" [8, p. 225] to do so. 
In-store technologies pose various opportunities for luxury retail stores. For example, they allow bringing personalized and information-intensive experiences or entertaining and pleasurable elements to physical stores [4]. They also enable hybrid customer interactions [24] and generate omni-channel experiences [6], which can drive customers' in-store shopping intentions [7]. In-store technologies offer various customer touchpoints (TPs), which may impact customers' technology acceptance [25]. "A customer touchpoint is a stimulus fulfilling a specific role within the customer journey. It has an interface, which grants access to the stimulus and is mediated by a human, an analog object, or a technology situated in a physical or digital sphere. When encountering a touchpoint, a message between the customer and the retailer, its brand, or other customers is transmitted. This encounter causes a customer experience" [26, p. 7]. Brick-and-mortar retailers can complement their stores with in-store technologies and e-service TPs to work toward an omni-channel environment [cf. 9, 25]. "Service is defined as the application of specialized competences [...], through deeds, processes, and performances for the benefit of another entity or the entity itself' [27, p. 26]. A brick-and-mortar e-service TP is a customer-directed electronic service (e-service) offering that is mediated by a digital TP interface (e.g., a terminal or smartphone) in the physical servicescape [25].

While some customers perceive digital TP interfaces as more trustworthy and objective than the sales staff [28], consumers in the luxury segment and their emotional involvement with products are influenced by sales assistants [4]. Thus, sales assistants should not be replaced. Indeed, digital and human TP interfaces can complement each other [28]. Heine and Berghaus [8] offer luxury brands some guidance on digital interfaces such as online shops, review sites, or mobile and tablet applications. Their work suggests that e-service TPs should be carefully developed to ensure that they offer customer benefits and reflect the brand's superior luxury and quality. However, prior works provide little guidance on the selection of brick-and-mortar e-service TPs [25].

As stated above, customers have different expectations when buying goods purchased on an irregular basis. This also applies to the purchase of luxury watches. Just as in the luxury retail industry in general, mono-brand stores are losing ground to authorized online retailers and e-boutiques of watch brands [2]. Thus, this article focuses on e-service TPs complementing the employee-mediated watch-advisory service in physical jewelry stores. A sales talk on watches usually comprises five phases [29, p. 145]: Salutation, needs analysis, product presentation, purchase, and conclusion. The majority of these phases take place at a sales desk. Therefore, such a desk can be considered a suitable medium for a digital interface offering e-service TPs.

In a project with the carpentry business August Kreienbaum $\mathrm{GmbH}$, which develops and realizes interior designs for jewelers, the authors designed a concept for a touchsensitive screen embedded in a sales desk in the context of the Mittelstand 4.0Kompetenzzentrum Lingen. This concept is called 'digital sales desk' in the following. The concept's requirements were defined in discussions between the project partners and interviews with jewelry stores. As stated above, luxury customers have different expectations when buying goods purchased on an irregular basis [11-13]. The interviews reflected these expectations. As a result, several potential e-service TPs were defined (see Table 1) to support jewelers' watch-advisory service. 
Table 1. Potential E-Service Touchpoints for the Digital Sales Desk

\begin{tabular}{|c|c|c|}
\hline Cat. & Touchpoint & Description \\
\hline \multirow{4}{*}{ 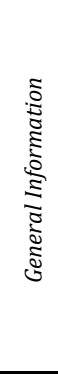 } & $\begin{array}{l}\text { Jeweler } \\
\text { Information }\end{array}$ & $\begin{array}{l}\text { Some customers value the brand of the jeweler itself. Thus, this TP allows the customer } \\
\text { to gain insight into the history of the jeweler. }\end{array}$ \\
\hline & $\begin{array}{l}\text { Watch Pro- } \\
\text { motion Video }\end{array}$ & $\begin{array}{l}\text { When no customer is sitting at the sales desk or the consultation has not yet begun, this } \\
\text { TP displays promotional videos of products and manufacturers on the screen. }\end{array}$ \\
\hline & $\begin{array}{l}\text { Watch } \\
\text { Catalog }\end{array}$ & $\begin{array}{l}\text { To provide an overview of the existing watches, a digitalized product catalog [cf. 30] can } \\
\text { be displayed on the digital sales desk. }\end{array}$ \\
\hline & $\begin{array}{l}\text { Brand } \\
\text { Websites \& } \\
\text { Apps }\end{array}$ & $\begin{array}{l}\text { Some manufacturers provide (web) applications for concessionaire businesses. These } \\
\text { are often accessed via tablets or computers of the jewelers. By granting access to them, } \\
\text { this TP should increase their accessibility. }\end{array}$ \\
\hline \multirow{3}{*}{ 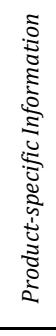 } & $\begin{array}{l}\text { Watch } \\
\text { Information } \\
\text { \& Pictures }\end{array}$ & $\begin{array}{l}\text { When a watch with an RFID transponder is placed on the RFID reader or a watch is } \\
\text { selected from the catalog, this TP presents essential information about it [e.g., 25]. 3D- } \\
\text { images allow customers to see watches in detail }[\text { cf. } 8,29,30] \text {. }\end{array}$ \\
\hline & $\begin{array}{l}\text { Watch Part } \\
\text { Details }\end{array}$ & $\begin{array}{l}\text { This TP presents information on specific watch parts, such as the watch bezel or face, on } \\
\text { a separate view to not overload the product information page. }\end{array}$ \\
\hline & $\begin{array}{l}\text { Watch Brand } \\
\text { Information }\end{array}$ & $\begin{array}{l}\text { Many customers are interested in the brand of a product. Information on the brand's } \\
\text { history and, if applicable, on characters related to the brand, such as designers, can be } \\
\text { conveyed vividly using the screen [31]. }\end{array}$ \\
\hline \multirow{5}{*}{ 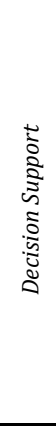 } & $\begin{array}{l}\text { Watch } \\
\text { Comparison }\end{array}$ & $\begin{array}{l}\text { If a customer cannot decide between watches, a comparison TP can provide the most } \\
\text { important facts about the watches to support the decision-making [e.g., } 25,32] \text {. }\end{array}$ \\
\hline & $\begin{array}{l}\text { Watch } \\
\text { Configuration }\end{array}$ & $\begin{array}{l}\text { Many watches are available in different materials and designs. The digital sales desk } \\
\text { displays these options and enables a simple product configuration. }\end{array}$ \\
\hline & $\begin{array}{l}\text { Similarity- } \\
\text { based Recom. }\end{array}$ & $\begin{array}{l}\text { This TP presents products with similar characteristics on the product information page } \\
\text { [e.g., 25]. }\end{array}$ \\
\hline & $\begin{array}{l}\text { Customer- } \\
\text { based Recom. }\end{array}$ & $\begin{array}{l}\text { Many customers trust the opinions of other customers [33]. Thus, this TP presents } \\
\text { products that customers with similar preferences have bought. }\end{array}$ \\
\hline & $\begin{array}{l}\text { Purchase- } \\
\text { based Recom. }\end{array}$ & $\begin{array}{l}\text { Personalization is becoming increasingly important to customers in the luxury segment } \\
\text { [34]. Thus, this TP makes suggestions based on customers' prior purchases [e.g., 25]. }\end{array}$ \\
\hline \multirow{3}{*}{$\underset{\substack{\Xi \\
\vdots}}{\vdots}$} & $\begin{array}{l}\text { Availability. } \\
\text { \& Deli. Time }\end{array}$ & $\begin{array}{l}\text { This TP provides quick information on the availability of watches in the store. If not } \\
\text { available, the digital sales desk also provides information on delivery times [e.g., 25]. }\end{array}$ \\
\hline & Payment & $\begin{array}{l}\text { The purchase is often carried out at the sales desk. Thus, this TP can execute payments } \\
\text { and display invoices [29]. }\end{array}$ \\
\hline & $\begin{array}{l}\text { Contact } \\
\text { Formula }\end{array}$ & $\begin{array}{l}\text { Long-term customer contact management beyond a purchase requires the collection of } \\
\text { contact data [29]. Thus, the digital sales desk mediates a contact formula TP. }\end{array}$ \\
\hline
\end{tabular}

Luxury customers' have various reasons to shop online [33]. Among other things, luxury customers appreciate the availability of product information, customer reviews, exclusive online offers, user-friendliness, brand information, convenient returns, and product presentation when shopping online [1]. The digital sales desk allows retailers to mirror some benefits of e-commerce to the physical servicescape [cf. 25], such as the availability of product and brand information and the digital product presentation. Besides, it offers complimentary entertaining and pleasurable elements [cf. 4] for the watch-advisory service. Thus, the e-service TPs may meet the luxury customers' 
functional and hedonic needs [cf. 20, 22]. In addition, the provided brand- and watchspecific information conveys individual brands' values [cf. 23]. The seamless integration of brand websites and apps ensures that the brands' superior luxury and qualities are reflected [cf. 8]. Finally, the digital sales desk supports salespersons through quick access to information. Thus, it may support jewelers to meet their customers' expectance for sophisticated personal service [cf. 12].

The concept visualized the e-service TPs with mockups (see example in Figure 1a). Besides, the tapdo technologies $\mathrm{GmbH}$ developed a simple hardware prototype (see Figure $1 b$ ) housing a radio-frequency identification (RFID) reader that automatically detects watches equipped with RFID transponders [cf. e.g., 35]. The digital TP interface still needs to be implemented based on its ex-ante evaluation [cf. 15], which is presented in this manuscript.

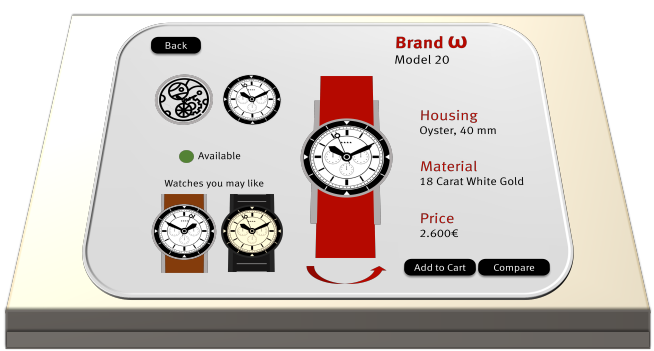

(a)

Watch Faces \& Clockwork licensed as Creative Commons CCBY (Noun Project: John Burraco \& Eucalyp)

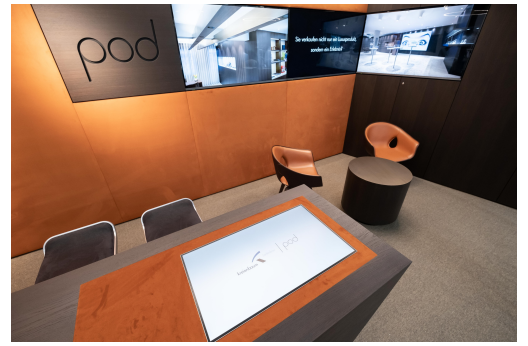

(b)

Figure 1. (a) Exemplary Mockup and (b) Hardware Prototype of the Digital Sales Desk

\section{Research Model and Hypotheses Development}

Luxury customers' quality expectations of the service provided are high [13]. For customers, the quality of service results from comparing their expectations with their perceptions [36]. The aim of a retailer should be to meet or even exceed the expectations of its customers to achieve a high-quality service [cf. 37]. Customers' evaluations of service quality result from the sum of encounters with service TPs [38]. Therefore, retailers must ensure that customers perceive the overall quality of the digitally supported service at the digital sales desk as high. Prior studies have identified relationships between quality, customer value, customer satisfaction, and customers' behavioral intentions $[39,40]$. The relationships between the constructs discussed below are congruent with Kettinger et al. [17] and Haddad Rezende et al. [41].

The individually perceived probability that a person will act in a certain way is called the person's behavioral intention [42]. In the digital sales desk's context, retailers need to ensure that customers intend to re-use the digitally supported advisory service in the jeweler's store. According to some prior studies, service quality perceptions directly affect customers' behavioral intentions [40, 43]. In contrast, others have not investigated this theoretical relationship $[17,18]$ or could not confirm a direct relationship [44]. Thus, the first hypothesis is: 
H1: Customers' perceptions of the digital sales desk's quality positively impact their intentions to (re-)use a jeweler's digitally supported watch-advisory service.

The behavioral intentions of customers are influenced by their experiences and impressions. Customers' perceptions of value and their satisfaction positively impact their behaviors [e.g., 39, 45]. Thus, besides the direct effects of quality perceptions on behavioral intentions, prior research also found indirect effects of service quality via customers' perceptions of value and their satisfaction [40, 43].

In the context of products, "perceived value is the consumer's overall assessment of the utility of a product based on perceptions of what is received and what is given" [46, p. 14]. Literature also uses this definition in the context of service and shopping values [e.g., 18, 47]. In retailing, costs can be reduced, or benefits can be increased to strengthen customers' value perceptions [48]. The costs for customers in making a purchase not only comprise monetary resources but also include the time, risks, and efforts involved [17, 48]. The customers' benefits include utilitarian (e.g., quality products, personalized offers, or shopping convenience), hedonic, or social values [12, 17, 48]. When introducing new technology, retailers should consider how such an introduction affects value perceptions [48]. Thus, as the digital sales desk aims at supporting and improving the advisory service, the second and third hypotheses are:

H2: Customers' perceptions of the digital sales desk's quality positively impact their values perceived from a jeweler's digitally supported watch-advisory service.

H3: Customers' perceptions of a digitally supported watch-advisory service's value positively impact their intentions to (re-)use the service.

In the context of smart retailing, customers' impressions and evaluations of cumulative experiences with technologies also impact their satisfaction [49, 50]. Customers' satisfaction in general results from their perceptions of service quality [17, 38]. Customers' evaluations of service quality are based on the comparison of their expectations before the purchase with their perceptions after the purchase [18]. Prior research has found that service quality perceptions can increase satisfaction [41, 43]. Furthermore, perceptions of value were shown to drive customers' perceptions of satisfaction [18, 39, 43, 44], and studies have shown that customers' satisfactions influence behavioral and purchase intentions [39, 44, 45, 51]. Satisfied customers are more likely to consider re-consuming or using a service, technology, or system [39, 41, $49,52]$. Thus, the last hypotheses read as follows:

H4: Customers' perceptions of the digital sales desk's quality positively impact their perceptions of satisfaction with a jeweler's watch-advisory service.

H5: Customers' perceptions of a digitally supported watch-advisory service's value positively impact their perceptions of satisfaction with the service.

H6: Customers' perceptions of satisfaction with a digitally supported watch-advisory service positively impact their intentions to (re-)use the service. 


\section{$4 \quad$ Method}

Measures and Questionnaire: The survey items were adopted from prior research and adapted to the study context. The established WebQual (WQ) model was chosen to measure customers' Perceived Quality of the digital sales desk. $W Q$ was developed to assess the quality of websites [53,54]. As the digital sales desk aims at complementing physical jewelry stores with e-service TPs similar to those known from e-commerce [25], it can be argued that it is appropriate to utilize $W Q$ in this context. For this study, the $W Q$ measurement items were adapted from Loiacono et al. [53, 54]. $W Q$ comprises 36 survey items for 12 reflective first-order constructs, partly determining three formative second-order constructs (see Figure 2). Perceived Quality is a third-order formative construct. Satisfaction was measured according to four items adapted from Haddad Rezende et al. [41]. The measurement instruments for the Value were adapted from Kettinger et al. [17], who based them on the value categories of Sweeney and Soutar [55]. Besides, the items used by two studies [17, 41] were combined to investigate the customers' (Re-)Use Intentions toward the advisory service. Figure 2 shows this study's research model, including its six hypotheses, fifteen first-order constructs, three second-order constructs (i.e., Usefulness, Ease of Use, Entertainment), and one third-order construct (i.e., Perceived Quality). Similar to prior studies [25, 56], a single survey item ("Please indicate how likely you would be to use the following features:") was added to the survey to measure customers' willingness to use the individual e-service TPs. All survey items were adapted to fit the study's context and translated to German. As the online survey's goal was the artificial, formative, ex-ante evaluation [cf. 15] of the digital sales desk, the items were also transformed into their conjunctive forms.

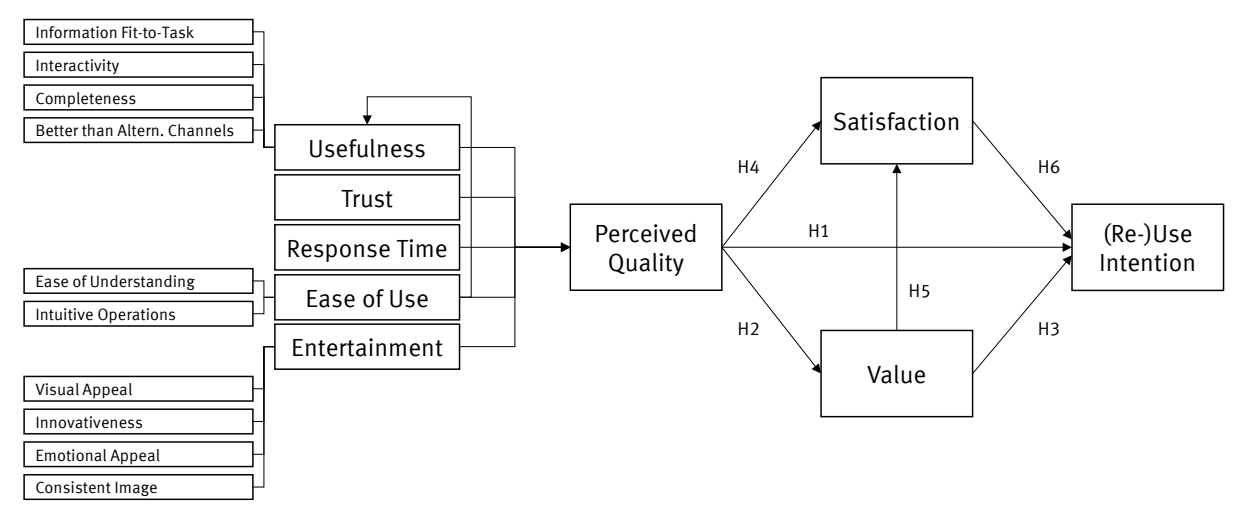

Figure 2. Research Model Based on WebQual

Data Collection Procedure and Sampling: A quantitative online survey was conducted to assess the digital sales desk's concept. In addition to the possibility of surveying a large sample of people, online surveys ensure that respondents are not influenced by the social interaction that occurs during face-to-face or telephone 
surveys. Each respondent receives the same questions, which increases the comparability of the results. Also, online surveys facilitate asking complex questions with many possible answers [57]. A seven-point Likert-like scale was employed to record the responses. The use of a Likert scale is particularly suitable for questions that cannot always be answered with "yes" or "no," but instead with a tendency [57].

The survey started with an introduction to the collaborative project. Based on a textual description and pictures from a jewelry store, participants were asked to put themselves in the situation of a sales conversation. Next, the idea of the digital sales desk was explained in the context of this situation. For further description and clarification, a picture of the prototype and a two-minute animated explanation video (https://youtu.be/pSTK1glTuEI) followed. The participants could review the introductory descriptions at any time. To foster the participants' understanding further, they had to rate the individual e-service TPs at the beginning of the survey. Also, participants could leave comments on the functions in a free-text field. Subsequently, the participants were guided through the $W Q$, Value, Satisfaction, and (Re-Use) Intention items. Finally, several control variables (i.e., an affinity for technology [58], willingness to pay for watches, purchase of a watch in the last two years, age, and gender) concluded the survey. Except for the free-text fields and demographic questions, all questions were mandatory.

The online survey was realized with the tool LimeSurvey [59]. In the period from 29.04.2020 to 21.05.2020, participants were invited over personal networks, social networks, and e-mail inquiries. To reach participants interested in luxury watches, profiles, blogs, and groups focusing on watches were directly approached.

Data Analysis: The Partial Least Squares (PLS) method was used to carry out the data analysis. It allows making predictions on concrete data points with small sample size and without demands on the data distribution [60]. The PLS and bootstrapping algorithms of SmartPLS 3 were utilized to drive the evaluation of the measurement model and the subsequent analysis of the data [61, 62]. As $W Q$ comprises formative second-order and third-order constructs next to its reflective first-order constructs, the repeated indicator approach was chosen for the final model [63].

\section{$5 \quad$ Results}

\subsection{Sample Characteristics and E-Service Touchpoint Preferences}

In total, 128 people participated in the survey. 29 of 128 participants started the survey but did not finish it. Consequently, 99 fully completed surveys were considered to evaluate and analyze the data (see Table 2). Disregarding 14 participants that did not state their gender, roughly the same number of females and males participated. The average age of the survey participants was approximately 33 years. Most participants' willingness to pay (WTP) for a watch was up to $500 €$ and had a moderate technology affinity. Above $50 \%$ of the participants had bought a watch in the last two years. 
Table 2. Demographic Information of the Sample and two Sub-Samples

\begin{tabular}{|c|c|c|c|c|c|c|c|}
\hline \multicolumn{2}{|l|}{ WTP (Sub-)Sample } & \multicolumn{2}{|c|}{$\operatorname{All}(n=99)$} & \multicolumn{2}{|c|}{$\leq 500(n=53)$} & \multicolumn{2}{|c|}{$>500(n=46)$} \\
\hline Items & Cat. & Freq. & $\%$ & Freq. & $\%$ & Freq. & $\%$ \\
\hline \multirow[t]{3}{*}{ Gender } & Female & 41 & $41.41 \%$ & 35 & $66.04 \%$ & 6 & $13.04 \%$ \\
\hline & Male & 44 & $44.44 \%$ & 14 & $26.42 \%$ & 30 & $65.22 \%$ \\
\hline & N/A & 14 & $14.14 \%$ & 4 & $7.55 \%$ & 10 & $21.74 \%$ \\
\hline \multirow[t]{4}{*}{ Age } & $18-30$ & 67 & $67.68 \%$ & 39 & $73.58 \%$ & 28 & $60.87 \%$ \\
\hline & $31-40$ & 8 & $8.08 \%$ & 2 & $3.77 \%$ & 6 & $13.04 \%$ \\
\hline & $41-50$ & 9 & $9.09 \%$ & 5 & $9.43 \%$ & 4 & $8.70 \%$ \\
\hline & $>50$ & 15 & $15.15 \%$ & 7 & $13.21 \%$ & 8 & $17.39 \%$ \\
\hline \multirow{7}{*}{$\begin{array}{l}\text { Willingness to Pay } \\
\text { (WTP) }\end{array}$} & $\leq 100$ & 11 & $11.11 \%$ & 11 & $20.75 \%$ & 0 & $0.00 \%$ \\
\hline & $\leq 500$ & 42 & $42.42 \%$ & 42 & $79.25 \%$ & 0 & $0.00 \%$ \\
\hline & $\leq 800$ & 7 & $7.07 \%$ & 0 & $0.00 \%$ & 7 & $15.22 \%$ \\
\hline & $\leq 2400$ & 11 & $11.11 \%$ & 0 & $0.00 \%$ & 11 & $23.91 \%$ \\
\hline & $\leq 7000$ & 15 & $15.15 \%$ & 0 & $0.00 \%$ & 15 & $32.61 \%$ \\
\hline & $\leq 20000$ & 9 & $9.09 \%$ & 0 & $0.00 \%$ & 9 & $19.57 \%$ \\
\hline & $>20000$ & 4 & $4.04 \%$ & 0 & $0.00 \%$ & 4 & $8.70 \%$ \\
\hline \multirow{3}{*}{$\begin{array}{l}\text { Affinity for Tech. } \\
\text { (Ø Over } 4 \text { Items; } \\
\text { (1=Low; } 7=\text { High) }\end{array}$} & [1-3[ & 5 & $5.05 \%$ & 4 & $7.55 \%$ & 1 & $2.17 \%$ \\
\hline & {$[3-5[$} & 69 & $69.70 \%$ & 44 & $83.02 \%$ & 25 & $54.35 \%$ \\
\hline & [5-7] & 30 & $30.30 \%$ & 9 & $16.98 \%$ & 21 & $45.65 \%$ \\
\hline \multirow{2}{*}{$\begin{array}{l}\text { Bought Watch in } \\
\text { the last two Years }\end{array}$} & Yes & 51 & $51.52 \%$ & 27 & 50.94 & 24 & $52.17 \%$ \\
\hline & No & 48 & $48.48 \%$ & 26 & 49.06 & 22 & $47.83 \%$ \\
\hline
\end{tabular}

The participants' willingness to use the e-service TPs is shown in Figure 3. Overall, participants were most willing to use the Watch Information \& Pictures, Watch Comparison, Watch Configuration, and Watch Part Details TPs. The most unpopular e-service TPs were the Jeweler Information, Watch Brand Websites \& Apps, and Watch Promotion Video. The preferences slightly differed for the sub-samples with low and high WTP. For example, the Watch Brand Information, Watch Brand Websites and Apps, and Jeweler Information TPs were more preferred by the high WTP sub-sample. The participants' comments provided further insights into their perceptions of the individual e-service TPs. First, it was noted that the decision to buy a watch is personal. Recommendations based on purchases of other customers were said to be of little help. Second, it was stated that the purchase of a watch is a rare activity. Thus, it would be challenging to create a good customer profile for product recommendations. One participant also noted that the screen would be too large to enter personal data. Four respondents explained that the payment is very important in a high price segment and should not be digitalized too much. Besides, participants argued that information about different brands and the jeweler would not be of much interest and would be, if at all, more relevant before entering the store. It was also stressed that the digital sales desk should not replace essential elements of the physical store - in particular, the sales staff and the opportunity to try on products. Finally, it should fit the store equipment, and 
the graphical user interface should be clear and scalable such that people with impaired vision can also use it.

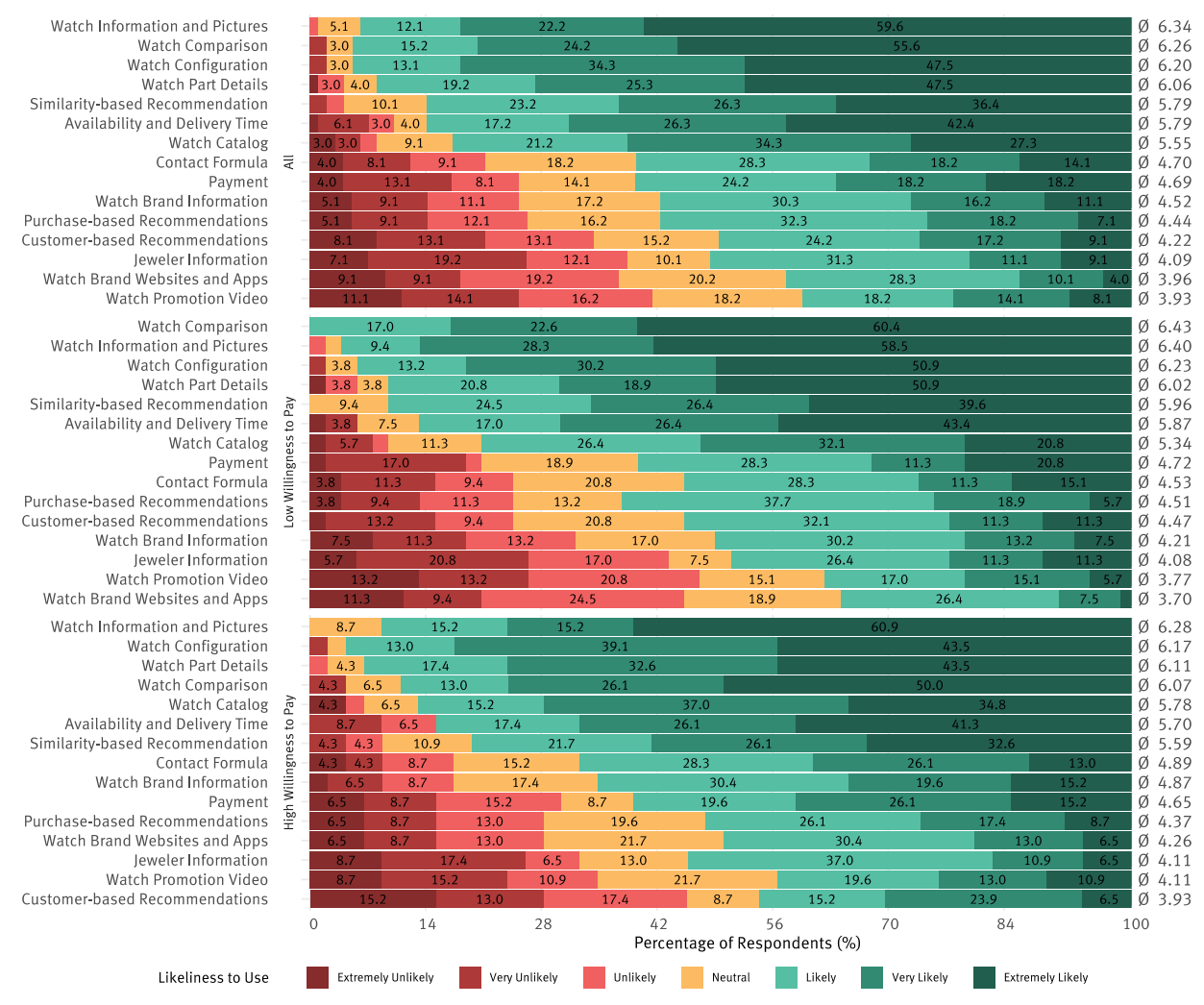

(Desc. Order of Average Score; 1=Extremely Unlikely; 7=Extremely Likely)

Figure 3. Participants' Willingness to Use the Jeweler E-Service Touchpoint

\subsection{Results Concerning the Measurement and Structural Model}

The measurement model's reliability and validity were examined following Hair et al. [62]. As the research model comprises second-order and third-order constructs, a combination of the repeated indicator and the two-stage approach [63] was employed to evaluate the model's formative parts before calculating the final results. For the PLS algorithm, the default path weighting scheme, 500 maximum iterations, and a stop criterion of $10^{-7}$ were selected. Bootstrapping was performed with 5000 samples [62].

First, the reflective first-order constructs were evaluated [62]. The evaluation only reported a low Cronbach's Alpha for the Response Time construct and identified two items with loadings lower than the threshold value of .7 (Trust \#3 and Response Time \#3). As a result, only Response Time \#3, which was the inverted attention item, was removed from the model. This removal improved the Cronbach's Alpha, the Composite Reliability, and the Average Variance Explained [62, 64]. The analysis of the 
cross-loadings supported the decision to drop this item. While the HeterotraitMonotrait ratio (HTMT) Correlation between Interactivity and Information Fit-to-Task (.938) exceeded the critical value of .9 [62], the HTMT Confidence Intervals did not encompass the value 1 [65]. Therefore, no changes were needed.

Second, the formative second-order and third-order $W Q$ constructs were evaluated [62]. When considering the collinearity, the Variance Inflation Factor did not exceed the critical value of 5 for any of the formative indicators. Concerning the significance and relevance of the formative indicators, insignificant weights for Intuitive Operations, Trust, Response Time, and Ease of Use were discovered. Still, whereas Intuitive Operations, Ease of Use, and Response Time had significant loadings larger than .5, Trust had a significant loading slightly below .5 (.462). Thus, the first three can still be considered absolute contributors to their higher-order constructs [62]. As $W Q$ is an established research model, the latter formative indicator was retained.

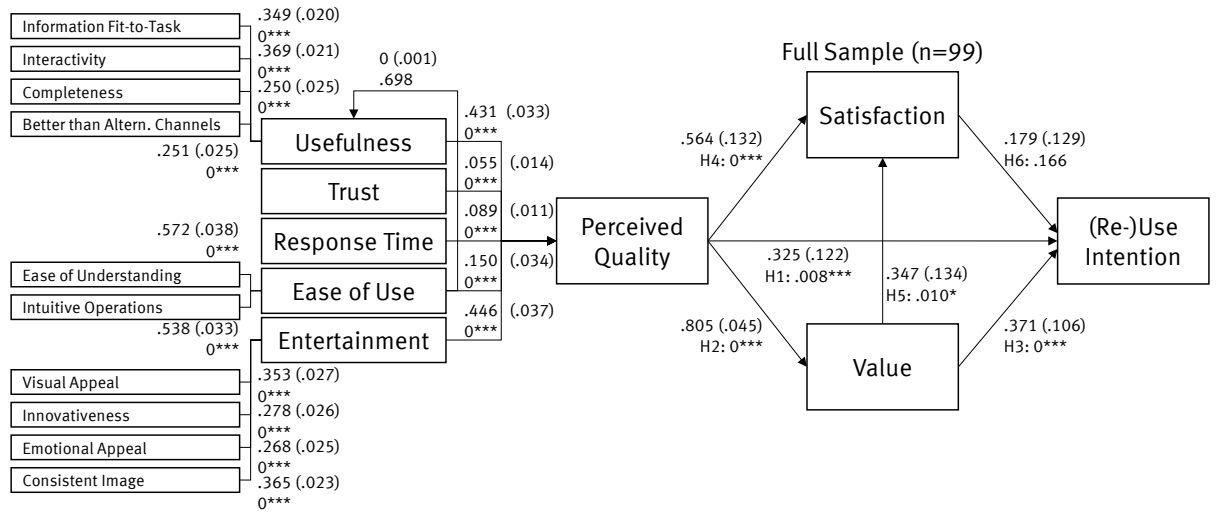

Figure 4. Structural Models with Path Coefficients

Hair et al.'s [62] six steps were followed to examine the final structural model (see Figure 4): First, the Variance Inflation Factors are examined to check all driver constructs for collinearity. All values were beneath the threshold value of 5. Next, considering the relevance and significance of the path coefficients, some path coefficients had low values. Thus, the significances of these relationships were checked. All relationships, besides those between Ease of Use and Usefulness, and between Satisfaction and (Re-)Use Intention, were significant in the full sample. Except for the relationship between Value and Satisfaction, which showed a significance level of $5 \%$, all significant relationships had a significance level of $1 \%$. Besides the relationships of Ease of Use and Usefulness, and Satisfaction and (Re-)Use Intention, the confidence intervals did not encompass zero. As a result, only hypothesis $H 6$ had to be rejected, and the impact of Ease of Use on Usefulness was insignificant in the full sample. Entertainment and Usefulness, and their lower-order constructs, Consistent Image, Interactivity, Visual Appeal, and Information-Fit-to-Task, had the most substantial mediated total effects on Satisfaction, Value, and (Re-)Use Intention and the latter four also on Perceived Quality. Next, the coefficients of determination $\left(R^{2}\right.$-values $)$ 
were considered and, following Hair et al. [62], all $R^{2}$-values besides of Value (.648) and (Re-)Use Intention (.674), which can be considered as moderate, could be regarded as substantial (i.e., larger than .75). When examining the $f^{2}$-effect strength, according to Hair et al. [62], a strong and significant effect strength was only found for the relationship between Perceived Quality and Value. All other relationships between the exogenous and endogenous constructs had insignificant moderate (i.e., between Value and Satisfaction) or low effect strengths. Next, the forecast relevance was checked by considering the cross-validated redundancies of the constructs reported by the blindfolding algorithm. The $Q^{2}$-values of the endogenous reflective indicators were all above zero, suggesting that all have forecast relevance. Finally, the $q^{2}$-effect strengths were evaluated. Following Hair et al. [62], Perceived Quality had a moderate forecast relevance for Satisfaction and a low one for (Re-)Use Intention. Satisfaction and Value had low forecast relevance for each other and (Re-)Use Intention.

\section{Discussion}

The survey suggests that the relationships between Perceived Quality and Satisfaction (H4), Value (H2), and (Re-)Use Intention (H1) are significant. Participants' perceptions of Value also affected their perceptions of Satisfaction (H5) and (Re-)Use Intentions (H3). In contrast, the hypothesis that perceptions of Satisfaction lead to (Re-)Use Intentions (HO) had to be rejected (see Figure 4). For the low WTP sub-sample (see Figure 5), $H 4$ had to be rejected. For the high WTP sub-sample, $H 1$ and $H 3$ had to be rejected, but $H 6$ could be accepted, and the effect of Value on Satisfaction was stronger (H4). The results contribute to the discourse on the direct $(\mathrm{HI})$ and indirect relationships (e.g., H6) between Perceived Quality and (Re-)Use Intention [cf. 40, 43, 44].

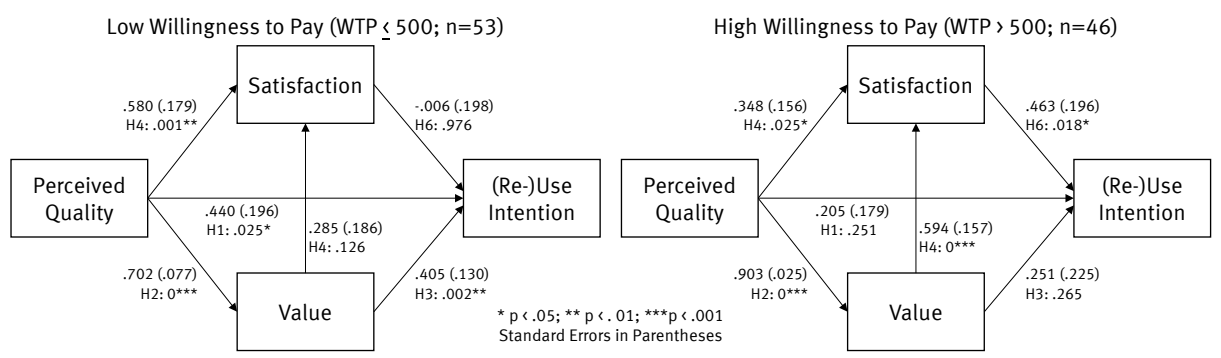

Figure 5. Hypothesis Testing for Sub-Samples

$W Q$ 's $[53,54]$ first- and second-order constructs can provide clues for interpreting the results and improving the concept further. By considering the total effects in the structural model, the constructs with the highest (mediated) impact on Perceived Quality and (Re-)Use Intention could be identified [62]. In the full sample, Entertainment, Usefulness, Consistent Image, Interactivity, Visual Appeal, Information Fit-to-Task, and Ease of Use had the strongest effects in descending order. For the low WTP sub-sample, Visual Appeal and Ease of Use had a stronger effect than Consistent Image, Interactivity, and Information Fit-to-Task. For the high WTP sub-sample, 
Usefulness was more important than Entertainment. Besides, Visual Appeal and Ease of Use were less important for this sub-sample than for the low WTP sub-sample. Overall, the items of Visual Appeal had an approval rate of above $70 \%$ and, thus, positively contributed to the Perceived Quality and (Re-Use) Intention. When considering the individual items of Information Fit-to-task and Interactivity, it is noticeable that over $70 \%$ of the participants agreed with all questions except for the question that dealt with whether the digital sales desk is exactly what a customer needs to support the purchase. Similarly, almost $40 \%$ of respondents did not agree with the Completeness item "All my business with the jeweler could be completed via the digital sales desk" [adapted from 53,54]. Thus, the concept could be further improved concerning these areas for improvement. Still, the optional survey comments and the existing literature suggest that the digital sales desk should support rather than replace the sales assistants [cf. 28]. Consequently, more research is required to determine an optimal set of complementary TPs offered via human and digital interfaces in jewelry stores. Another construct hints at room for improvement is the Consistent Image. Around $60 \%$ of the participants agreed with the questions addressing this topic. Thus, further efforts could concentrate on improving the concept regarding the Consistent Image. Also, while only having a slightly lower total effect, another area for potential improvement is the Emotional Appeal. About 33\% of the participants stated that using the digital sales desk would not positively impact their happiness. As brand experience is particularly relevant in luxury retailing [5], customers' emotions should be considered when developing the concept further. Furthermore, even though several participants critically commented on the storage of personal data and the digital support of the payment process, Trust had the lowest impact on customers' perceptions of quality and their intentions to (re-)use the service. Still, only $28 \%$ of the participants stated that they would not feel secure when carrying out transactions at the sales desk. Thus, future research should focus on the impact of Trust on customers' perception of digital interfaces in luxury retail stores.

Overall, e-service TPs increasing the efficiency and effectiveness of the customer journey were most popular (e.g., Watch Information \& Pictures, Watch Comparison, and Watch Configuration). In contrast, less popular were the personalized e-service TPs (i.e., the Purchase- and Customer-based Recommendation TPs). Thus, personalization in the smart servicescape [49] of jewelers should be investigated further.

\section{Conclusion}

E-commerce retailers have adopted TPs from the physical servicescape and adapted them for e-commerce to substitute for some of brick-and-mortar retail's distinct benefits (e.g., trying on products virtually). To comply with their customers' changing expectations, brick-and-mortar retailers can do the opposite and mirror e-service TPs from e-commerce to the physical servicescape. However, existing research only provides little guidance on the selection of brick-and-mortar e-service TPs. Especially, more research on e-service TPs for brick-and-mortar retailers selling specific product categories is required [25]. 
This article proposed a digital sales desk offering various potential e-service TPs to support jewelers' watch-advisory services. It also investigates the factors that affect customers' perceptions of the sales desk's quality and their impacts on customers' intentions to (re-)use the digitally supported watch-advisory service. Therefore, customers' willingness to use the proposed e-service TPs and their perceptions of the digital sales desk's quality as a whole were assessed in an online survey. In addition, the digital sales desk's impact on customers' satisfaction with, values derived from, and intentions to (re-)use the digitally supported watch-advisory service were evaluated. The results suggest that the e-service TPs are not equally desired by customers. Furthermore, perceptions of the digital sales desk's quality and the value derived from the advisory service affected the participants' (re-)use intentions toward the service. The results differed for two sub-samples. From a theoretical perspective, this article contributes to the knowledge base on customers' expectations regarding a specific instore technology in luxury retail [e.g., 4]. From a practical viewpoint, examples of promising e-service TPs are provided, which can be implemented by watch-selling luxury retailers. The results also provide orientation on the aspects of a digital sales desk, which need to consider during its implementation.

This article leaves room for future research. First, most participants were interested in watches costing up to $500 €$. While the results of the high WTP sub-sample (including $46.46 \%$ of the survey participants) provide an idea of a higher paying customer group's perceptions, future research could consider this customer group in more detail. Second, the survey results can now be used to revise the prototype. Subsequently, formative or summative evaluations can be conducted in lab experiments or field studies in cooperation with jewelry stores [cf. 15]. As $84 \%$ of the participants agreed with a strong tendency that the digital sales desk would be innovative, it might allow jewelers to gain competitive advantages [4] and meet their customers' changing expectations.

\section{Acknowledgments}

This work was created in the context of a project that received funding from the Bundesministerium für Wirtschaft und Energie (BMWi) under the grant agreement 01MF17011D.

\section{References}

1. Lüdemann, S.: Luxury Goods Marktreport 2020. Statista (2020).

2. Statista: Zukünftig wichtige Vertriebskanäle von Unternehmen der Uhrenbranche in ausgewählten Ländern weltweit in den Jahren 2015 bis 2017, https://statista.com/statistik/daten/studie/466212/, last accessed 2020/11/29.

3. Dauriz, L., Remy, N., Sandri, N.: Luxury Shopping in the Digital Age: Perspectives on Retail and Consumer Goods. Perspect. Retail Consum. Goods. Summer, 26-31 (2014).

4. Pantano, E., Passavanti, R., Priporas, C.-V., Verteramo, S.: To what Extent Luxury Retailing can be Smart? J. Retail. Consum. Serv. 43, 1-28 (Preprint) (2018).

5. Klein, J.F., Falk, T., Esch, F.-R., Gloukhovtsev, A.: Linking Pop-Up Brand Stores to Brand Experience and Word of Mouth: The Case of Luxury Retail. J. Bus. Res. 69, 5761-5767 (2016). 
6. Bèzes, C.: What Kind of In-Store Smart Retailing for an Omnichannel Real-Life Experience? Rech. Appl. en Mark. (English Ed. 34, 91-112 (2019).

7. Shi, S., Wang, Y., Chen, X., Zhang, Q.: Conceptualization of Omnichannel Customer Experience and its Impact on Shopping Intention: A Mixed-Method Approach. Int. J. Inf. Manage. 50, 325-336 (2020).

8. Heine, K., Berghaus, B.: Luxury goes Digital: How to Tackle the Digital Luxury BrandConsumer Touchpoints. J. Glob. Fash. Mark. 5, 223-234 (2014).

9. Aiolfi, S., Sabbadin, E.: Fashion and New Luxury Digital Disruption: The New Challenges of Fashion between Omnichannel and Traditional Retailing. Int. J. Bus. Manag. 14, 41-51 (2019).

10. Blázquez, M.: Fashion Shopping in Multichannel Retail: The Role of Technology in Enhancing the Customer Experience. Int. J. Electron. Commer. 18, 97-116 (2014).

11. Burke, R.R.: Technology and the Customer Interface: What Consumers Want in the Physical and Virtual Store. J. Acad. Mark. Sci. 30, 411-432 (2002).

12. Choo, H.J., Moon, H., Kim, H., Yoon, N.: Luxury Customer Value. J. Fash. Mark. Manag. 16, 81-101 (2012).

13. Türk, B., Scholz, M., Berresheim, P.: Measuring Service Quality in Online Luxury Goods Retailing. J. Electron. Commer. Res. 1, 88-103 (2012).

14. Patas, J., Milicevic, D., Goeken, M.: Enhancing Design Science through Empirical Knowledge: Framework and Application. In: Jain, H., Sinha, A.P., and Vitharana, P. (eds.) Service-Oriented Perspectives in Design Science Research. DESRIST 2011. Lecture Notes in Computer Science, vol 6629. pp. 32-46. Springer, Milwaukee, WI, USA (2011).

15. Venable, J., Pries-Heje, J., Baskerville, R.: FEDS: A Framework for Evaluation in Design Science Research. Eur. J. Inf. Syst. 25, 77-89 (2016).

16. Pantano, E.: Innovation Drivers in Retail Industry. Int. J. Inf. Manage. 34, 344-350 (2014).

17. Kettinger, W.J., Park, S.-H. "Sunny", Smith, J.: Understanding the Consequences of Information Systems Service Quality on IS Service Reuse. Inf. Manag. 46, 335-341 (2009).

18. Oh, H.: Service Quality, Customer Satisfaction, and Customer Value: A holistic Perspective. Int. J. Hosp. Manag. 18, 67-82 (1999).

19. Wang, Y.-S.: Assessing E-Commerce Systems Success: A Respecification and Validation of the DeLone and McLean Model of IS Success. Inf. Syst. J. 18, 529-557 (2008).

20. Bian, Q., Forsythe, S.: Purchase Intention for Luxury Brands: A Cross Cultural Comparison. J. Bus. Res. 65, 1443-1451 (2012).

21. Kapferer, J.-N., Laurent, G.: Where do Consumers think Luxury Begins? A Study of Perceived Minimum Price for 21 Luxury Goods in 7 Countries. J. Bus. Res. 69, 332-340 (2016).

22. Kim, S., Park, G., Lee, Y., Choi, S.: Customer Emotions and their Triggers in Luxury Retail: Understanding the Effects of Customer Emotions Before and After Entering a Luxury Shop. J. Bus. Res. 69, 5809-5818 (2016).

23. Dion, D., Borraz, S.: Managing Status: How Luxury Brands Shape Class Subjectivities in the Service Encounter. J. Mark. 81, 67-85 (2017).

24. Nüesch, R., Alt, R., Puschmann, T.: Hybrid Customer Interaction. Bus. Inf. Syst. Eng. 57, 73-78 (2015)

25. Barann, B., Betzing, J.H., Niemann, M., Hoffmeister, B., Becker, J.: Exploring Customers' Likeliness to Use E-Service Touchpoints in Brick and Mortar Retail. Electron. Mark. 1-23 (2020).

26. Barann, B., Hermann, A., Heuchert, M., Becker, J.: Can't Touch This? Conceptualizing the Customer Touchpoint in the Context of Omni-Channel Retailing. J. Retail. Consum. Serv. $1-11(2020)$. 
27. Vargo, S.L., Lusch, R.F.: Why "Service”? J. Acad. Mark. Sci. 36, 25-38 (2008).

28. Vannucci, V., Pantano, E.: Digital or Human Touchpoints? Insights from Consumer-Facing In-Store Services. Inf. Technol. People. 33, 296-310 (2019).

29. Duma, F.: Management der persönlichen Interaktion im Verkauf von Luxusgütern: Eine Untersuchung am Beispiel von Schweizer Luxusuhren, https://digitalcollection.zhaw.ch/handle/11475/14672, (2018).

30. El Azhari, J., Bennett, D.: Omni-Channel Customer Experience: An Investigation into the Use of Digital Technology in Physical Stores and its Impact on the Consumer's DecisionMaking Process. In: XXIV AEDEM International Conference London. pp. 1-13. London South Bank University, London, UK (2015).

31. Dion, D., Arnould, E.: Retail Luxury Strategy: Assembling Charisma through Art and Magic. J. Retail. 87, 502-520 (2011).

32. Parise, S., Guinan, P.J., Kafka, R.: Solving the Crisis of Immediacy: How Digital Technology Can Transform the Customer Experience. Bus. Horiz. 59, 411-420 (2016).

33. Liu, X., Burns, A.C., Hou, Y.: Comparing Online and In-Store Shopping Behavior Towards Luxury Goods. Int. J. Retail Distrib. Manag. 11/12, 885-900 (2013).

34. Pantano, E., Dennis, C.: Smart Retailing: Technologies and Strategies. Palgrave Pivot, Cham, Switzerland (2019).

35. Hauser, M., Griebel, M., Hanke, J., Thiesse, F.: Empowering Smarter Fitting Rooms with RFID Data Analytics. In: Proceedings of the 13th International Conference on Wirtschaftsinformatik (WI 2017). pp. 1299-1302., St.Gallen, Switzerland (2017).

36. Parasuraman, A., Zeithaml, V.A., Berry, L.L.: A Conceptual Model of Service Quality and its Implications for Future Research. J. Mark. 49, 41-50 (1985).

37. Parasuraman, A., Berry, L.L., Zeithaml, V.A.: Unterstanding Customer Expectations of Service. Sloan Manage. Rev. 39, (1991).

38. Pantano, E., Viassone, M.: Engaging Consumers on New Integrated Multichannel Retail Settings: Challenges for Retailers. J. Retail. Consum. Serv. 25, 106-114 (2015).

39. Chen, C.-F., Chen, F.-S.: Experience Quality, Perceived Value, Satisfaction and Behavioral Intentions for Heritage Tourists. Toursim Manag. 31, 29-35 (2010).

40. Choi, K.-S., Cho, W.-H., Lee, S., Lee, H., Kim, C.: The Relationships Among Quality, Value, Satisfaction and Behavioral Intention in Health Care Provider Choice. J. Bus. Res. 57, 913-921 (2004).

41. Haddad Rezende, N.E., Cunha Moura, L.R., Wasner Vasconcelos, F.C., da Silveira Cunha, N.R.: Proposition and Test of a Quality Assessment Extension WebQual Model in Brazil. Rev. Eur. Stud. 9, 74-90 (2017).

42. Foroudi, P., Gupta, S., Sivarajah, U., Broderick, A.: Investigating the Effects of Smart Technology on Customer Dynamics and Customer Experience. Comput. Human Behav. 80, 271-282 (2018).

43. Cronin, J.J., Brady, M.K., Hult, G.T.M.: Assessing the Effects of Quality, Value, and Customer Satisfaction on Consumer Behavioral Intentions in Service environments. J. Retail. 76, 193-218 (2000).

44. Huang, Y.-K.: The Effect of Airline Service Quality on Passenger's Behavioural Intentions Using SERVQUAL Scores: A Taiwan Case Study. J. East. Asia Soc. Transp. Stud. 8, 23302343 (2010).

45. Cronin, J.J., Taylor, S.A.: Measuring Service Quality: A Reexamination and Extension. J. Mark. 56, 55-68 (1992).

46. Zeithaml, V.A.: Consumer Perceptions of Price, Quality, and Value: A Means-End Model and Synthesis of Evidence. J. Mark. 52, 2-22 (1988). 
47. Willems, K., Smolders, A., Brengman, M., Luyten, K., Schöning, J.: The Path-to-Purchase is Paved with Digital Opportunities: An Inventory of Shopper-Oriented Retail Technologies. Technol. Forecast. Soc. Change. 124, 228-242 (2017).

48. Inman, J.J., Nikolova, H.: Shopper-Facing Retail Technology: A Retailer Adoption Decision Framework Incorporating Shopper Attitudes and Privacy Concerns. J. Retail. 93, 7-28 (2017).

49. Roy, S.K., Balaji, M.S., Sadeque, S., Nguyen, B., Melewar, T.C.: Constituents and Consequences of Smart Customer Experience in Retailing. Technol. Forecast. Soc. Change. 124, 257-270 (2017).

50. Homburg, C., Koschate, N., Hoyer, W.D.: The Role of Cognition and Affect in the Formation of Customer Satisfaction: A Dynamic Perspective. J. Mark. 70, 21-31 (2006).

51. van Birgelen, M., de Jong, A., de Ruyter, K.: Multi-Channel Service Retailing: The Effects of Channel Performance Satisfaction on Behavioral Intentions. J. Retail. 82, 367-377 (2006).

52. Pantano, E., Viassone, M.: Demand Pull and Technology Push Perspective in TechnologyBased Innovations for the Points of Sale: The Retailers Evaluation. J. Retail. Consum. Serv. 21, 43-47 (2014).

53. Loiacono, E.T., Watson, R.T., Goodhue, D.L.: WebQual: A Measure of Web Site Quality. Am. Mark. Assoc. 13, 432-438 (2002).

54. Loiacono, E.T., Watson, R.T., Goodhue, D.L.: WebQual: An Instrument for Consumer Evaluation of Web Sites. Int. J. Electron. Commer. 11, 51-87 (2007).

55. Sweeney, J.C., Soutar, G.N.: Consumer Perceived Value: The Development of a Multiple Item Scale. J. Retail. 77, 203-220 (2001).

56. Lazaris, C., Vrechopoulos, A., Doukidis, G., Fraidaki, K.: Mobile Apps for Omnichannel Retailing: Revealing the Emerging Showrooming Phenomenon. In: Proceedings of the 9th Mediterranean Conference on Information Systems (MCIS 2015). pp. 1-17. , Samos, Greece (2015).

57. Bernard, H.R.: Social Research Methods: Qualitative and Quantitative Methods. Sage Publications, Thousand Oaks, California, US (2013).

58. Agarwal, R., Prasad, J.: A Conceptual and Operational Definition of Personal Innovativeness in the Domain of Information Technology. Inf. Syst. Res. 9, 204-215 (1998).

59. LimeSurvey: LimeSurvey: An Open Source Survey Tool, https://www.limesurvey.org/, last accessed 2020/11/29.

60. Huber, F., Herrmann, A., Meyer, F., Vogel, J., Vollhardt, K.: Kausalmodellierung mit Partial Least Squares. Gabler, Wiesbaden, Germany (2007).

61. Ringle, C.M., Wende, S., Becker, J.-M.: SmartPLS3, http://smartpls.com, (2015).

62. Hair, J.F., Hult, G.T.M., Ringle, C.M., Sarstedt, M., Richter, N.F., Hauff, S.: Partial Least Squares Strukturgleichungsmodellierung. Franz Vahlen, Munich, Germany (2017).

63. Becker, J.-M., Klein, K., Wetzels, M.: Hierarchical Latent Variable Models in PLS-SEM: Guidelines for Using Reflective-Formative Type Models. Long Range Plann. 45, 359-394 (2012).

64. Götz, O., Liehr-Gobbers, K.: Analyse von Strukturgleichungsmodellen mit Hilfe der PartialLeast-Squares (PLS)-Methode. Die Betriebswirtschaft. 64, 714-738 (2004).

65. Henseler, J., Ringle, C.M., Sarstedt, M.: A new Criterion for Assessing Discriminant Validity in Variance-Based Structural Equation Modeling. J. Acad. Mark. Sci. 43, 115-135 (2015). 